\title{
BENTUK DAN PENGGUNAAN KATA PENGGOLONG BENDA DI PASAR INDUK TRADISIONAL DI JAKARTA DAN SURABAYA
}

\author{
Nadra, Sri Wahyuni, dan Mahsun \\ FIB Universitas Andalas dan FKIP Universitas Mataram \\ E-mail:nadra_1963@yahoo.co.id
}

\begin{abstract}
Abstrak
Penelitian ini bertujuan untuk mendeskripsikan bentuk-bentuk kata penggolong benda dan penggunaannya oleh penutur Indonesia dalam jual beli di pasar induk tradisional di Jakarta dan Surabaya. Data dikumpulkan melalui penyimakan dan wawancara. Untuk menganalisis data digunakan metode padan intralingual. Temuan penelitian ini sebagai berikut. Pertama, kata penggolong benda yang ditemukan ada empat puluh tiga bentuk. Kedua, kata penggolong benda tersebut dapat diklasifikasikan atas tiga jenis, yaitu: (a) kata penggolong benda individual, (b) kata penggolong benda kolektif, dan (c) kata penggolong benda yang berupa satuan ukuran. Ketiga, kata penggolong benda yang dominan digunakan di pasar induk tradisional di Jakarta dan Surabaya adalah kata penggolong benda yang berupa satuan ukuran. Hal itu disebabkan dalam jual beli memang diperlukan ukuran yang jelas.
\end{abstract}

Kata kunci: kata penggolong benda, satuan ukuran, pasar induk tradisional

\section{FORMS AND USES OF NOUN CLASSIFIERS IN TRADITIONAL CENTRAL MARKETS IN JAKARTA AND SURABAYA}

\begin{abstract}
This study aims to describe forms of noun classifiers and their uses by Indonesian speakers in transactions in traditional central markets in Jakarta and Surabaya. The data were collected through listening and interviewing. They were analyzed by the intralingual correspondence technique. The research findings are as follows. First, there are 43 forms of noun classifiers. Second, they can be classified into three categories, i.e.: (a) individual noun classifiers, (b) collective noun classifiers, and (c) noun classifiers in the form of measurement units. Third, the dominant noun classifiers in traditional central markets in Jakarta and Surabaya are noun classifiers in the form of measurement units. This is due to the fact that transactions need precise measurements.
\end{abstract}

Keywords: noun classifiers, measurement units, traditional central markets

\section{PENDAHULUAN}

Salah satu unsur penting yang berperan dalam menumbuhkan rasa nasionalisme dan membangun karakter bangsa Indonesia adalah bahasa Indonesia. Oleh sebabitu, pemertahanan, pembinaan, dan pengembangan bahasa Indonesia harus terus dilakukan. Sejauh pengamatan yang dilakukan, pengembangan kosa kata ba- hasa Indonesia dalam bidang teknologi informasi dan komunikasi hampir tidak digali dari bahasa Indonesia sendiri, melainkan lebih berkiblat pada bahasa asing. Hal itu antara lain terlihat pada penggunaan kata penggolong benda dalam jual beli. Oleh sebab itu, perlu dilakukan kajian tentang kata penggolong benda yang digunakan oleh penutur Indonesia. 
Yang dimaksud dengan penutur Indonesia dalam tulisan ini adalah penutur dari berbagai daerah di Indonesia yang bertutur dalam konteks bahasa Indonesia. Hasilnya dapat dimanfaatkan untuk mengantisipasi maraknya intervensi penggunaan bahasa asing tersebut.

Pembicaraan pada tulisan ini difokuskan pada bentuk-bentuk kata penggolong benda dan penggunaannya oleh penutur Indonesia dalam jual beli di pasar induk tradisional di dua kota besar di Indonesia, yakni di Jakarta dan Surabaya. Pemilihan lokasi di pasar induk tradisional di kedua kota besar itu dilakukan dengan alasan bahwa penggunaan kata penggolong benda lebih dominan di kedua tempat tersebut.

Kata penggolong benda merupakan kata yang memegang peranan penting sebab kata tersebut mempunyai fungsi untuk mengelompokkan benda. Kata ituhadir bersamaan dengan adanya benda. Tanpa adanya kata penggolong dalam mengelompokkan benda, maka komunikasi tidak akan berjalan dengan lancar. Contohnya, jika seseorang akan membeli beras, apabila dia hanya mengatakan beras $d u a$, jelas mitra bicaranya akan kebingungan. Apakah yang dimaksud dengan dua di situ adalah dua karung, dua liter, atau dua kilogram.

Sejauh ini, istilah yang digunakan untuk kata penggolong benda juga berbedabeda. Dalam bahasa Indonesia dikenal beberapa istilah untuk menyebut kata penggolong benda, di antaranya adalah kata penunjuk jenis, kata bantu bilangan, kata penggolong, kata satuan, dan kata penyukat. Istilah kata penunjuk jenis dikemukakan oleh Hadidjaja (1959:36-108). Yang dimaksudkannya dengan kata penunjuk jenis adalah kata yang menghubungkan kata bilangan dengan kata benda, seperti orang, ekor, buah, batang, dan keping. Istilah kata bantu bilangan digunakan oleh Keraf (1984:78), Brataatmaja(1987:85), Walujeng (2002:165), dan Wahyuni (2010), sedang- kan istilah kata penggolong digunakan oleh Kridalaksana (1994:71), Hasan (2000:282), dan Kentjono dkk. (2004:188). Di samping istilah kata penggolong, Kentjono dkk. (2004:190) juga membedakannya dengan istilah kata pengukur. Sementara itu, Ramlan dalam dua bukunya yang berbeda menyebut kategori ini dengan dua istilah yang berbeda pula. Dalam bukunya yang berjudul Morfologi: Suatu Tinjauan Deskriptifyang terbit pada tahun 1983, Ramlan menyebutnya dengan kata satuan. Sebaliknya, dalam bukunya yang berjudul Tata Bahasa Indonesia: Penggolongan Kata yang terbit tahun 1991 ia menyebutnya dengan kata penyukat. Yang dimaksudkannya dengan kata penyukat adalah kata yang terletak setelah kata bilangan dan sebelum kata nominal dan bersama kata itu membentuk satu frasa yang disebut dengan frasa bilangan, misalnya: kata orang, ekor, buah, kodi, kotak, dan meter.

Meskipun terdapat beberapa istilah yang digunakan para ahli untuk menamakan kategori ini, pada tulisan ini digunakan istilah kata penggolong benda, yang dimaksudkan sama artinya dengan numeral classifier. Istilah numeral classifier digunakan oleh Aikhenvald (2000), Yamamoto dan Keil (2000), dan Wahyuni (2006). Aikhenvald (2000:98) menggunakan istilah numeral classifier sebagai salah satu istilah dari delapan golongan classifier yang dikelompokkannya.

Selanjutnya, kata penggolong benda yang diperoleh diklasifikasikan atas tiga jenis, mengikuti klasifikasi yang dilakukan oleh Mizuguchi (2004:13), yakni kata penggolong benda individual, kata penggolong benda kolektif, dan kata penggolong benda yang menyatakan ukuran. Yang dimaksud dengan kata penggolong benda individual adalah kata penggolong benda untuk menghitung unit terkecil atau untuk menghitung secara satu persatu benda-benda padat yang nyata, dan untuk masing-masing benda tersebut digunakan kata penggolong benda tertentu. 
Kata penggolong benda kolektif adalah kata penggolong untuk menghitung benda-benda yang terbentuk dari dikumpulkannya beberapa unit terkecil atau beberapa individual. Kata penggolong tipe ini bukanlah menyatakan jumlah anggota dari perkumpulan tersebut, melainkan berpusat pada kelompok yang terbentuk dari beberapa anggota. Kata penggolong benda ukuran adalah kata penggolong pembantu ketika mengukur suatu benda berdasarkan ukurannya dan benda tersebut dipahami bukan sebagai unit terkecil dari benda itu sendiri.

\section{METODE}

Penelitian ini menggunakan dasar ilmu bahasa (linguistik). Secara deskriptif, penelitian ini dilakukan semata-mata hanya berdasarkan pada fakta yang ada atau fenomena yang memang secara empiris hidup pada penutur-penuturnya. Pengumpulan data dilakukan dengan cara penyimakan di lapangan dan wawancara.

Penyimakan dilakukan di pasar induk tradisional yang terdapat di dua kota besar di Indonesia. Penyimakan ini dilakukan dengan cara: (a) peneliti berpartisipasi penuh (peneliti menyembunyikan peran); (b) pengamat sebagai partisipan (peran peneliti diketahui); (c) partisipan sebagai pengamat (peran partisipan lebih kuat daripada peran pengamatan; dan (d) pengamat penuh (peneliti mengamati tanpa berpartisipasi) (Creswell, 2002:140). Pengamatan ini juga diikuti dengan pencatatan.

Wawancara dilakukan dengan cara terstruktur dan tidak terstruktur. Wawancara terstruktur dilakukan dengan menggunakan sejumlah pertanyaan yang telah disusun dalam daftar pertanyaan yang berfungsi untuk memancing jawaban. Pada waktu wawancara, diusahakan untuk langsung berhadapan dengan orang yang diwawancarai (informan). Sudaryanto (1993:138) menamakan teknik ini sebagai teknik cakap semuka. Jawaban informan langsung dicatat pada kertas yang sudah disediakan. Penulisan jawaban dilakukan secara ortografis. Apabila informan memberikan keterangan yang meragukan, pada saat itu juga ditanyakan lagi dengan cara yang berbeda. Wawancara tidak terstruktur dilakukan tergantung pada situasi yang terjadi pada waktu pengumpulan data di lapangan.

Daftar pertanyaan berisi nama benda yang dijual di pasar, sedangkan yang dijadikan sebagai informan utama adalah pedagang. Pemilihan pedagang sebagai informan utama dengan alasan bahwa pedaganglah yang setiap saat menggunakan kata penggolong benda ini dalam berjualan.

Dalam menganalisis data digunakan metode padan intralingual sebagaimana dikemukakan oleh Mahsun (2005:112-115). Yang dimaksud metode padan intralingual adalah metode analisis data dengan cara menghubungbandingkan unsurunsur yang bersifat lingual. Teknik dasar metode ini ada tiga macam, yaitu teknik hubung banding menyamakan (HBS), teknik hubung banding membedakan (HBB), dan teknik hubung banding menyamakan hal pokok (HBSP). Metode ini beserta tekniknya dianggap cocok untuk menganalisis data. Selanjutnya, hasil analisis ini disajikan secara naratif.

\section{HASIL DAN PEMBAHASAN}

Sesuai dengan fokus penelitian, berikut ini dikemukakan bentuk-bentuk kata penggolong benda yang ditemukan. Selanjutnya, kata penggolong benda tersebut diklasifikasikan atas tiga jenis mengikuti klasifikasi yang dikemukakan oleh Mizuguchi (2004:13). Bersamaan dengan klasifikasi itu sekaligus dijelaskan penggunaan setiap kata penggolong benda tersebut.

Berdasarkan data yang diperoleh, ditemukan empat puluh tiga bentuk kata penggolong benda yang digunakan dalam 
jual beli di pasar induk tradisional di Jakarta dan Surabaya. Dari keempat puluh tiga bentuk tersebut, tiga puluh empat di antaranya digunakan, baik di pasar tradisional di Jakarta maupun di Surabaya. Kata penggolong dimaksud adalah: (1) keranjang, (2) peti, (3) dus, (4) ikat, (5) sisir, (6) tandan, (7) biji, (8) karung, (9) kantong, (10) toples, (11) kaleng, (12) bungkus, (13) batang, (14) slof, (15) botol, (16) pak, (17) buah, (18) potong, (19) pasang, (20) set, (21) butir, (22) pot, (23) polibek, (24) kodi, (25) lusin, (26) ekor, (27) lembar, (28) rol, (29) meter, (30) kuintal, (31) ton, (32) liter, (33) kilo (kilogram), dan (34) tangkai.

Selanjutnya, ada kata penggolong benda yang hanya digunakan di pasar induk tradisional di Jakarta. Kata penggolong benda yang dimaksud ada empat bentuk, yaitu: (1) pajangan, (2) pis, (3) renceng, dan (4) gabung. Sebaliknya, ada pula kata penggolong benda yang hanya digunakan di pasar tradisional di Surabaya. Kata penggolong benda tersebut ada lima bentuk, yaitu: (1) renteng, (2) lonjor, (3) rimpang, (4) krat, dan (5) sak.

Kata penggolong benda yang ditemukan dapat diklasifikasikan atas tiga jenis, yaitu: kata penggolong benda individual, kata penggolong benda kolektif, dan kata penggolong benda yang menyatakan satuan ukuran.

\section{Kata Penggolong Benda Individual}

Berdasarkan data yang ada, ditemukan sembilan bentuk kata penggolong benda yang termasuk jenis kata penggolong benda individual, yaitu: biji, batang, pis, buah, lembar, ekor, butir, rol, dan lonjor. Penggunaan setiap kata penggolong tersebut dijelaskan sebagai berikut.

Pertama, biji. Kata penggolong biji merupakan kata penggolong yang paling banyak digunakan dalam berjual beli di pasar tradisional di Jakarta. Kata ini digunakan untuk: 1) pisang, 2) jambu biji, 3) mangga, 4) jeruk, 5) salak, 6) sirsak, 7) semangka, 8) melon, 9) sawo, 10) alpokat, 11) belimbing, 12) papaya, 13) jagung, 14) sabun mandi, 15) kol, 16) ubi rambat (ubi jalar), 17) tomat, 18) talas, 19) bawang putih, 20) supermi cup, 21) semua alat rumah tangga (seperti: kursi, lemari, sapu, tikar, tempat tidur), 22) semua alat masak (seperti: periuk, wajan ("kuali"), sendok masak), 23) semua alat makan (seperti: piring, sendok, gelas, mangkok), 24) pakaian (seperti: rok, daster, celana, pakaian dalam), 25) topi, 26) asesoris, 27) gorengan, 28) telur, dan 29) sabun cuci batangan. Sementara, di pasar induk tradisional di Surabaya, kata penggolong ini digunakan dalam jual beli untuk: 1) piring, 2) gelas, 3) kacamata, 4) jam tangan, 4) jam din-ding, 6) pompa air, 7) bantal, 8) kaus kaki, 9) kelapa, 10) keladi, dan 11) mentimun.

Kata biji mempunyai makna asal 'isi buah yang dapat tumbuh jika ditanam'. Di samping itu, bentuk biji juga digunakan sebagai kata penggolong benda untuk 'butir buah yang kecil-kecil'. Sementara, Kentjono dkk. (2004:188) menyatakan bahwa kata penggolong biji digunakan untuk mata, jagung, kelereng, dan padi. Dalam hal ini, lebih khusus lagi di pasar induk tradisional di Jakarta, kata penggolong biji digunakan bukan hanya untuk menyatakan buah yang kecil-kecil atau untuk benda yang menyerupai buah yang kecil-kecil, melainkan juga untuk semua jenis buah-buahan, peralatan rumah tangga, semua peralatan memasak, peralatan makan, pakaian, gorengan, dan asesoris. Jadi, kata penggolong biji digunakan juga untuk pengganti kata penggolong buah, helai, butir, bungkus, dan batang. Contoh: 2 biji melon, 1 biji lemari, 1 biji kelapa, 2 biji supermi, 3 biji rok, dan 1 biji topi.

Kedua, batang. Kata penggolong ini digunakan dalam jual beli rokok di pasar tradisional di Jakarta dan Surabaya untuk menunjuk pada satuan-satuan bendanya yang bentuknya bulat panjang. Contoh: 1 batang rokok. 
Ketiga, pis. Kata penggolong pis hanya digunakan di pasar induk tradisional di Jakarta untuk menunjuk pada benda yang berupa satuan, baik benda padat maupun benda cair yang dikemas sedemikian rupa, seperti: 1) sabun dan 2) benda-benda yang dikemas dalam bungkus kecil, misalnya: kopi instan, makanan ringan, dan sampo. Kata ini diduga berasal dari bahasa Inggris piece.Contoh: 1 pis kopi instan, 3 pis sampo, dan 1 pis kerupuk.

Keempat, buah. Kata penggolong buah digunakan di pasar induk tradisional di Jakarta untuk berjualan lemari, sedangkan di Surabaya digunakan untuk berjualan payung. Di samping kata penggolong buah, di pasar induk tradisional di Jakarta juga digunakan kata penggolong biji untuk berjualan lemari. Contoh: 1 buah lemari/1 biji lemari, 1 buah payung.

Kelima, lembar. Kata penggolong ini hanya digunakan oleh penjual di pasar induk tradisional di Jakarta dan Surabaya ketika menghitung lembaran daun pisang. Contoh: 10 lembar daun pisang.

Keenam, ekor. Kata penggolong ekor digunakan oleh pedagang ketika berjualan binatang yang masih hidup, seperti kambing dan ayam. Contoh: 1 ekor kambing, 3 ekor ayam. Jika kambing atau ayam itu sudah disembelih, kata penggolong yang digunakan adalah $\mathrm{kg}$.

Ketujuh, butir. Kata penggolong butir digunakan dalam berjualan telur. Akan tetapi, telur yang dijual menggunakan kata penggolong butir adalah telur yang telah direbus (telur matang), sedangkan telur mentah tidak dijual dalam hitungan butir, melainkan dalam $\mathrm{kg}$. Contoh: 1 butir telur (matang).

Kedelapan, rol. Rol adalah kata penggolong benda yang digunakan oleh pedagang dalam berjualan benda-benda yang dapat digulung, seperti: slang, tali, pita, dan benang. Kata ini termasuk kata penggolong berdasarkan bentuk dan merupakan kata penggolong benda individual. Contoh: 1 rol pita, 1 rol slang, 2 rol benang.
Kesembilan, lonjor. Kata penggolong lonjor hanya digunakan dalam jual beli di pasar tradisional di Surabaya untuk menjual pipa gorden. Panjang 1 lonjor adalah 6 meter. Lonjor merupakan satuan ukuran berdasarkan bentuk. Kata penggolong ini digunakan untuk mengukur pipa gorden dalam bentuk satu satuan. Oleh sebab itu, kata penggolong ini termasuk kata penggolong benda individual. Contoh: 2 lonjor pipa gorden.

\section{Kata Penggolong Benda Kolektif}

Kata penggolong benda kolektif ditemukan sebanyak tiga belas bentuk, yaitu: pajangan, ikat, tangkai, sisir, tandan, bungkus, renceng, renteng, pasang, gabung, slof, pak, dan set. Setiap kata penggolong tersebut dijelaskan sebagai berikut.

Pertama, pajangan. Kata penggolong pajangan hanya digunakan di pasar tradisional di Jakarta untuk mengelompokkan buah-buahan atas satu tumpukan besar. Buah-buahan yang ditumpuk berupa pajangan adalah buah-buahan yang berukuran besar, yaitu semangka, melon, dan jeruk bali. Buah-buahan tersebut disusun dengan rapi berupa tumpukan segi empat dan makin ke atas makin mengecil. Buah-buahan tersebut dijual secara grosir, bukan secara eceran atau satu per satu. Tumpukan yang dimaksud seperti tampak pada gambar berikut ini.

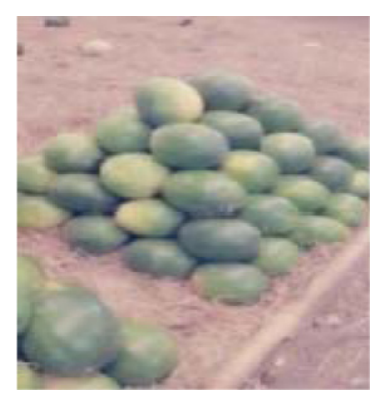

Gambar 1. Pajangan

Kata penggolong pajangan ini termasuk kata penggolong benda kolektif. Benda yang dikolektifkan dengan menggunakan kata penggolong ini jumlahnya 
juga tidak pasti. Berat setiap pajangan juga akan berbeda-beda. Oleh sebab itu, dalam berjualan, setiap pajangan juga akan diukur lagi dengan satuan yang pasti, yakni dengan cara menimbang setiap pajangan dengan ukuran $\mathrm{kg}$. Contoh: 1 pajangan semangka.

Kedua, ikat. Kata penggolong ikat, baik di pasar tradisional di Jakarta maupun di Surabaya, digunakan untuk mengelompokkan benda-benda berikut yang akan dijual, baik berupa partai besar (grosir) maupun yang dijual berupa partai kecil (untuk keperluan rumah tangga). Bendabenda yang dimaksud adalah: 1) nenas (isinya adalah $10 \mathrm{biji} / \mathrm{buah}$ ); 2) daun bawang, 3) daun seledri, 4) serai, 5) daun salam, 6) kangkung, dan 7) bayam.

Ikat termasuk kata penggolong benda kolektif, yakni disatukan dalam bentuk ikatan. Benda-benda individual dikelompokkan, kemudian diikat menjadi satu. Oleh karena itu, kata penggolong ini termasuk kata penggolong benda kolektif. Contoh: 2 ikat daun seledri, 1 ikat serai, 2 ikat bayam.

Ketiga, tangkai. Kata penggolong tangkai digunakan dalam jual beli bunga. Kata penggolong ini termasuk kata penggolong benda kolektif yang dipisahkan dari batang atau rumpunnya. Contoh: 2 tangkai bunga anggrek.

Keempat, sisir. Kata penggolong sisir digunakan dalam berjualan di pasar induk tradisional di Jakarta dan Surabaya untuk mengelompokkan pisang yang terdiri atas beberapa biji yang tersusun rapi dan terdiri atas dua baris. Kata penggolong ini termasuk ke dalam kata penggolong benda kolektif karena digunakan untuk mengelompokkan benda yang terdiri atas beberapa biji. Contoh: 1 sisir pisang.

Kelima, tandan. Kata penggolong ini juga digunakan dalam berjual beli di pasar induk tradisional di Jakarta dan Surabaya, yakni untuk mengelompokkan pisang yang terdiri atas beberapa sisir. Kata penggolong ini termasuk jenis kata penggolong benda kolektif karena mengelompokkan beberapa sisir pisang yang jumlahnya juga bervariasi. Contoh: 2 tandan pisang.

Keenam, bungkus. Kata penggolong bungkus digunakan, baik di pasar tradisional di Jakarta maupun di Surabaya untuk mengelompokkan benda yang dibalut dengan kertas, daun, atau plastik. Benda yang dimaksud adalah sabun cuci (deterjen) yang isinya tergantung pada besarnya bungkus. Benda lainnya adalah rokok yang isinya terdiri atas 12 batang/20 batang. Kata penggolong bungkus termasuk kata penggolong kolektif karena menyatukan benda individual dalam bentuk bungkusan. Contoh: 1 bungkus rokok.

Ketujuh, renceng. Renceng adalah kata penggolong benda yang digunakan di pasar tradisional di Jakarta dalam berjualan benda-benda yang ditempatkan di dalam kemasan kecil yang antara kemasan yang satu dengan kemasan yang lain saling beruntai. Biasanya 1 renceng terdiri atas 10 kemasan kecil. Benda-benda tersebut disatukan (dikolektifkan) dalam keadaan saling beruntai. Oleh karena itu, kata penggolong benda ini termasuk kata penggolong benda kolektif. Contoh: 1 renceng kopi kapal api, 2 renceng susu jahe.

Kedelapan, renteng. Kata penggolong ini digunakan dalam berjualan di pasar tradisional di Surabaya untuk menjual benda-benda yang ditempatkan di dalam kemasan kecil yang beruntai antara satu kemasan dengan kemasan yang lainnya. Bentuk ini mempunyai makna yang sama dengan renceng yang digunakan di Jakarta. Jadi, hanya terdapat perbedaan fonem antara bentuk yang digunakan di Jakarta dan yang digunakan di Surabaya, yakni fonem /t/ di Jakarta dan fonem /c/ di Surabaya. Benda-benda yang dijual dalam bentuk renteng ini antara lain adalah kopi instan dan deterjen bubuk. Kata penggolong renteng termasuk satuan ukuran berdasarkan bentuk dan termasuk kata penggolong benda kolektif. Contoh: 1 renteng deterjen bubuk. 
Kesembilan, pasang. Kata penggolong ini digunakan di pasar tradisional di Jakarta dan Surabaya dalam berjualan benda yang berpasangan, seperti: sepatu, sandal, dan kaus kaki. Pasang termasuk kata penggolong benda kolektif untuk benda yang berpasangan. Contoh: 1 pasang sepatu, 2 pasang kaus kaki.

Kesepuluh, gabung. Di pasar induk tradisional di Jakarta, kata penggolong gabung digunakan untuk menjual daun pisang. Daun pisang tersebut disatukan dalam satu gulungan yang isinya 20 lembar. Satu gulungan itu disebut dengan satu gabung. Contoh: 1 gabung daun pisang.

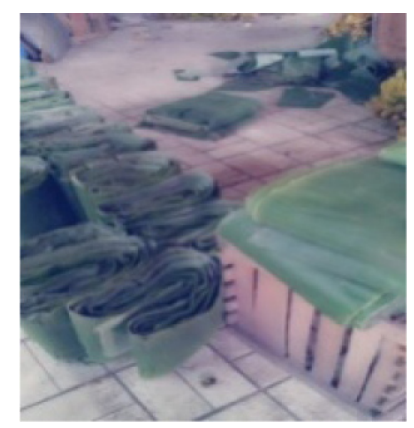

Gambar 2. Gabung

Kata penggolong gabung merupakan kata penggolong kolektif sebab benda itu dikolektifkan dalam bentuk gabungan.

Kesebelas, slof. Kata penggolong slof digunakan dalam jual beli rokok di pasar tradisional di Jakarta dan Surabaya untuk mengelompokkannya ke dalam ukuran yang lebih besar. Satu slof berisi 10 bungkus. Kata penggolong slof ini biasanya digunakan dalam jual beli secara grosir. Slof termasuk kata penggolong benda kolektif untuk benda yang dikumpulkan dalam jumlah yang tentu (ukuran yang pasti). Contoh: 2 slof rokok A Mild.

Keduabelas, pak. Kata penggolong ini digunakan dalam berjualan di pasar tradisional di Jakarta dan Surabaya untuk mengelompokkan benda dalam satu kemasan yang berisi barang dalam jumlah tertentu, misalnya 10 bungkus. Benda yang dimaksud antara lain adalah: rokok, garam, teh, dan berbagai macam kue kering, seperti biskuit. Pak termasuk kata penggolong benda kolektif yang menyatakan kumpulan dalam jumlah yang tentu (pasti). Contoh: 1 pak teh, 1 pakbiskuit, dan 1 pak garam.

Ketigabelas, set. Kata penggolong set digunakan pedagang ketika menjual benda-benda perabotan rumah tangga yang dipakai atau digunakan secara bersamasama, yang satu merupakan kelengkapan dari yang lain, seperti kursi dengan mejanya dan tempat tidur dengan lemarinya. Di samping itu, di pasar tradisional di Surabaya, bentuk ini juga digunakan untuk berjualan lampu hias. Contoh: 1 set tempat minum dan 1 set lampu hias.

\section{Kata Penggolong Benda yang Menyata- kan Satuan Ukuran}

Kata penggolong benda yang menyatakan satuan ukuran ditemukan sebanyak dua puluh satu bentuk, yaitu: keranjang, peti, dus, karung, kantong, toples, kaleng, botol, potong, pot, polibek, kodi, lusin, meter, kuintal, ton, liter, kilo (kilogram), rimpang, krat, dan sak. Penggunaan setiap kata penggolong tersebut dijelaskan sebagai berikut.

Kesatu, keranjang. Kata penggolong keranjang digunakan di pasar tradisional di Jakarta dan Surabaya untuk menjual buah-buahan secara grosir. Keranjang ini ada dua jenis, yaitu keranjang berukuran besar dan keranjang yang berukuran lebih kecil. Keranjang berukuran besar tidak memiliki tutup. Keranjang ini digunakan untuk menjual buah-buahan yang berukuran besar, seperti: jeruk bali, melon, dan semangka. Keranjang yang ukurannya lebih kecil memiliki tutup. Keranjang yang berukuran lebih kecil ini digunakan untuk menjual jeruk medan. Contoh: Satu keranjang jeruk bali.

Keranjang adalah kata penggolong benda satuan ukuran yang berupa wadah dan merupakan satuan ukuran dengan jumlah yang tidak akurat (yang tidak 
pasti). Isi keranjang biasanya berbedabeda dan setiap keranjang isinya akan diukur lagi dengan menggunakan ukuran yang pasti, yakni $\mathrm{kg}$.

Kedua, peti. Kata penggolong peti digunakan untuk menjual buah-buahan secara grosir di pasar induk tradisional di Jakarta dan Surabaya. Adapun buahbuahan yang dijual dengan menggunakan kata penggolong ini ada delapan macam, yaitu: 1) jambu biji, 2) mangga, 3) jeruk (Kalimantan), 4) belimbing, 5) salak, 6) sirsak, 7) alpokat, dan 8) sawo. Contoh: 3 peti mangga, 1 peti alpokat, dan 3 peti jeruk (Kalimantan).

Kata penggolong ini termasuk kata penggolong satuan ukuran yang berupa wadah dan merupakan satuan ukuran dalam jumlahyang tidak pasti. Isi peti biasanya juga berbeda-beda dan setiap peti akan diukur lagi isinya dengan menggunakan ukuran yang pasti, yakni $\mathrm{kg}$.

Ketiga, dus. Kata penggolong dus digunakan untuk mengelompokkan pisang impor yang dijual secara grosir di pasar induk tradisional di Jakarta dan Surabaya. Setiap dus berisi $15 \mathrm{~kg}$. Di samping untuk pisang impor, kata penggolong dus juga digunakan untuk menjual jahe secara grosir. Berbeda dengan isi dus untuk pisang impor, yakni berisi $15 \mathrm{~kg}$, isi dus untuk jahe adalah $10 \mathrm{~kg}$. Dus merupakan kata penggolong benda satuan ukuran yang berupa wadah. Contoh: 1 dus pisang (impor), 3 dus jahe.

Keempat, karung (lokal). Kata penggolong ini digunakan di pasar induk tradisional di Jakarta dan Surabaya untuk benda-benda berikut: 1) jeruk bali, 2) bawang putih, 3) bawang merah, 4) kentang, 5) wortel, 6) jagung, 7) cabe, 8) ubi jalar, 10) kol, dan 11) talas. Isi karung ini berkisar $50-54 \mathrm{~kg}$. Kata penggolong karung termasuk kata penggolong benda satuan ukuran yang berupa wadah. Biasanya untuk setiap karung, isinya diukur lagi berdasarkan ukuran yang pasti, yakni kg. Contoh: 1 karung bawang putih, 1 karung wortel, 3 karung cabe.
Kelima, kantong. Kata penggolong kantong digunakan dalam berjualan di pasar induk tradisional di Jakarta untuk menjual buncis, wortel, dan cabe yang sudah dimasukkan ke dalam tempat yang dibuat dari plastik. Isi setiap kantong berkisar antara $5-10 \mathrm{~kg}$. Kantong termasuk satuan ukuran berupa wadah. Contoh: 1 kantong buncis.

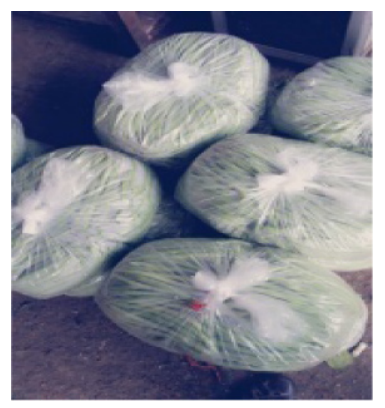

Gambar 3. kantong

Keenam, toples. Kata penggolong ini digunakan di pasar induk tradisional di Jakarta untuk menjual kue yang terdiri atas beberapa butiran kecil yang berisi 250 gram (satu perempat $\mathrm{kg}$ ), setengah kilogram, dan satu kilogram. Tempat kue ini terbuat dari plastik. Bentuknya ada yang segiempat dan ada yang bulat yang dikenal dengan istilah toples. Oleh karena toples merupakan suatu wadah, maka sebagai kata penggolong, bentuk ini dikelompokkan atas satuan ukuran berupa wadah. Contoh: 1 toples kue coklat.

Ketujuh, kaleng. Kata penggolong kaleng digunakan di pasar induk tradisional di Jakarta dan Surabaya dalam berjual beli untuk menggolongkan benda yang berupa cairan, seperti coca cola dan susu kental manis. Kata penggolong ini juga digunakan dalam berjualan untuk mengelompokkan benda yang halus, yakni susu bubuk. Di samping itu, kata penggolong ini juga digunakan dalam berjualan untuk mengelompokkan benda yang berupa makanan kecil dan makanan yang telah diawetkan, seperti biskuit dan makanan kalengan yang isinya antara lain 
adalah buah-buahan, daging, dan ikan laut. Kaleng dibuat dari besi tipis yang berlapis timah dengan ukuran yang bervariasi. Isi setiap kaleng biasanya diukur dengan satuan gram $(g)$ atau $\mathrm{ml}$. Contoh: 1 kaleng susu kental manis, 1 kaleng susu bendera.

Oleh karena kaleng berupa wadah, sebagai kata penggolong benda, kaleng ini termasuk kata penggolong satuan ukuran yang berupa wadah.

Kedelapan, botol. Kata penggolong botol digunakan dalam jual beli di pasar tradisional di Jakarta dan Surabaya untuk menggolongkan benda cair, seperti coca cola, teh, dan sirup (cairan yang ditempatkan di dalam botol). Botol ini biasanya dibuat dari kaca atau plastik, berbentuk bulat dan di atasnya berleher sempit. Contoh: 3 botol coca cola, 1 botol sirup.

Botol adalah sebuah wadah. Oleh karena itu, sebagai kata penggolong benda, kata ini termasuk kata penggolong satuan ukuran berupa wadah.

Kesembilan, potong. Kata penggolong potong digunakan ketika berjualan baju, celana, serbet, dan kain di kedua pasar induk tradisional. Di pasar induk tradisional di Jakarta juga digunakan bentuk lain untuk ini, yaitu bentuk biji. Selain itu, kata penggolong potong juga digunakan penjual di rumah makan untuk menjual telur dadar yang dipotong-potong ketika telur dadar itu dijual per potongnya. Kata penggolong potong merupakan kata penggolong benda yang berupa satuan ukuran yang menyatakan jumlah sebagian. Contoh: 2 potong baju, 1 potong celana, dan 3 potong serbet.

Kesepuluh, pot. Kata penggolong pot digunakan oleh penjual bunga untuk menjual bunga yang ditempatkan di dalam pot. Oleh karena pot adalah berupa wadah, kata penggolong benda ini termasuk kata penggolong satuan ukuran yang berupa wadah. Contoh: 1 pot bunga melati.

Kesebelas, polibek. Sama seperti pot, kata penggolong polibek juga digunakan untuk menjual bunga dan bibit tumbuhan lainnya. Oleh karena bahan tempat meletakkan bunga tersebut berbentuk polibek, kata penggolong yang digunakan adalah polibek. Kata penggolong ini merupakan kata penggolong satuan ukuran berupa wadah. Contoh: 1 polibek bunga talas, 5 polibek coklat.

Keduabelas, kodi. Kata penggolong kodi digunakan oleh pedagang untuk berjualan barang-barang secara grosir. Benda yang dijual secara grosir dalam hitungan kodi ini di antaranya adalah sepatu, sandal, dan tas. Kodi merupakan kata penggolong benda yang menyatakan satuan ukuran dalam jumlah yang pasti, yakni 20 buah. Oleh karena itu, kata penggolong ini merupakan kata penggolong yang menyatakan satuan ukuran dalam jumlah yang pasti. Contoh: 1 kodi tas, 3 kodi sepatu.

Ketigabelas, lusin. Sama seperti kodi, lusin juga merupakan kata penggolong benda yang digunakan oleh pedagang dalam menjual dagangannya secara grosir. Benda yang dijual dalam bentuk grosir yang menggunakan kata penggolong lusin adalah pakaian dan asesoris. Benda yang diperdagangkan dengan menggunakan kata penggolong lusin berjumlah 12 buah. Oleh karena jumlah benda yang dihitung dengan lusin berjumlah pasti, kata penggolong ini termasuk kata penggolong yang menyatakan satuan ukuran dalam jumlah yang pasti. Contoh: 1 lusin celana.

Keempatbelas, meter. Kata penggolong meter digunakan oleh pedagang dalam menjual benda-benda dalam ukuran panjang. Benda-benda, seperti slang, tali, pita, dan benang, selain dijual dalam bentuk rol (menggunakan kata penggolong rol), dapat pula dijual dalam meter. Meter merupakan kata penggolong satuan ukuran panjang yang berupa satuan ukuran yang digunakan secara internasional. Contoh: 5 meter slang.

Kelimabelas, kuintal. Kata penggolong kuintal merupakan kata penggolong satu- 
an ukuran berat. Berat 1 kuintal setara dengan 100 kg. Para pedagang di Jakarta menggunakan kata penggolong ini untuk berjualan beras. Contoh: 3 kuintal beras.

Keenambelas, ton. Sama seperti kuintal, kata penggolong ton juga merupakan kata penggolong untuk satuan berat. Kata penggolong ini di Jakarta juga digunakan pedagang dalam berjualan beras. Satu ton setara dengan $1000 \mathrm{~kg}$ atau 1 ton sama dengan 10 kuintal. Contoh: 1 ton beras.

Ketujuhbelas, liter. Kata penggolog liter adalah kata penggolong benda yang digunakan oleh pedagang dalam berjualan benda-benda yang berupa benda cair. Hampir semua benda cair dapat ditakar dengan menggunakan kata penggolong ini. Jenis benda cair yang ditakar dengan menggunakan kata penggolong liter oleh pedagang di Jakarta adalah minyak goreng, bensin, solar, dan pertamax. Liter merupakan kata penggolong satuan ukuran isi yang digunakan secara internasional. Contoh: 1 liter minyak goreng, 5 liter bensin.

Kedelapanbelas, kilo (kilogram). Kata penggolong kilo (kilogram) adalah kata penggolong yang digunakan untuk menakar benda-benda padat. Benda-benda yang dijual dengan menggunakan kata penggolong ini, seperti: telur, gula, kacang hijau, cabe, jahe, dan bawang putih. Kilo (kilogram) juga merupakan kata penggolong satuan ukuran berat yang digunakan secara internasional. Contoh: 2 kilo telur, 1 kilogram gula.

Kesembilanbelas, rimpang. Kata rimpang digunakan dalam jual beli di pasar tradisional di Surabaya untuk menunjuk pada benda yang berupa batang yang hidup menjalar di dalam tanah. Benda yang dimaksud adalah jahe dan kunyit.

Rimpang merupakan kata penggolong satuan ukuran. Setiap satu satuan jahe atau kunyit disebut satu rimpang. Kata penggolong ini digunakan untuk menyatakan bagian dari satu satuan benda yang dimaksud, maka kata penggolong ini da- pat dikelompokkan atas kata penggolong benda satuan ukuran yang menyatakan jumlah sebagian. Contoh: 2 rimpang jahe.

Keduapuluh, krat. Kata penggolong krat hanya ditemukan di pasar induk tradisional di Surabaya. Kata penggolong ini digunakan untuk mengelompokkan buah-buahan yang diletakkan di dalam peti yang terbuat dari plastik. Isi setiap krat dihitung dengan kilogram. Buahbuahan yang diletakkan di dalam krat ini adalah jeruk mandarin. Krat merupakan kata penggolong benda satuan ukuran yang berupa wadah dan termasuk satuan ukuran yang tidak pasti. Contoh: 1 krat jeruk mandarin.

Keduapuluhsatu, sak. Kata penggolong sak hanya digunakan dalam berjualan di pasar tradisional diSurabaya untuk menjual oyong, mentimun, dan daun bawang. Sak merupakan kata penggolong benda satuan ukuran yang berupa wadah dan termasuk satuan ukuran yang tidak pasti. Contoh: 1 sak mentimun.

Jika dikaji lebih lanjut, kata penggolong benda yang menyatakan satuan ukuran dapat pula dikelompokkan atas dua jenis, yaitu kata penggolong benda berupa satuan ukuran yang takarannya pasti dan kata penggolong benda yang berupa satuan ukuran yang takarannya tidak pasti. Kata penggolong benda berupa satuan ukuran dalam takaran yang pasti juga dapat dikelompokkan menjadi dua jenis, yakni satuan ukuran yang menyatakan jumlah yang akurat berdasarkan nilai ukuran yang menggunakan satuan ukuran internasional dan satuan ukurandengan takaran pasti yang menggunakan satuan ukuran Indonesia.

Kata penggolong yang berupa satuan ukuran dalam takaran yang pasti berdasarkan satuan ukuran internasional yang ditemukan di pasar tradisional di Jakarta dan Surabaya adalah satuan ukuran untuk ukuran panjang, berat, dan isi. Satuan ukuran yang digunakan untuk 
satuan ukuran panjang hanya ditemukan satu macam kata penggolong, yaitu meter,sedangkan untuk satuan ukuran beratditemukan tiga macam kata penggolong, yaitu kuintal, ton, dan kilogram. Selanjutnya, untuk satuan ukuran isi hanya ditemukan satu macam kata penggolong, yaitu liter.

Kata penggolong yang berupa satuan ukuran dalam takaran yang pasti yang menggunakan satuan ukuran Indonesia digunakan sebagai satuan ukuran yang menyatakan jumlah. Kata penggolong untuk satuan ukuran tersebut adalah kodi dan lusin. Selanjutnya, kata penggolong benda yang berupa satuan ukuran untuk takaran yang tidak pasti adalah: keranjang, peti,dus, karung, kantong, toples, kaleng, slof, botol,pak, pot, polibek, potong, dan karton. Di dalam satuan ukuran yang tidak pasti, biasanya juga terdapat ukuran yang pasti, seperti: kotak di dalamnya ada beberapa bungkus atau hanya ada satu benda tertentu; karung di dalamnya berisi 50-54 kilogram, renceng isi 10 bungkus, dan botol yang isinya juga bervariasi, seperti: $100 \mathrm{ml}$, $600 \mathrm{ml}$, atau $1000 \mathrm{ml}$.

Kata penggolong benda yang menyatakan satuan ukuran dengan takaran yang tidak pasti tersebut di atas juga dapat dikelompokkan atas 2 jenis, yaitu: (1) satuan ukuran yang berupa wadah dan (2) satuan ukuran yang menyatakan jumlah sebagian. Yang termasuk kelompok satuan ukuran yang berupa wadahadalah: keranjang, peti, dus, karung, kantong, toples, kaleng, botol, pot, slof,pak, polibek, dan karton. Kata penggolong yang termasuk ke dalam kelompok satuan ukuran yang menyatakan jumlah sebagian adalah rimpang dan potong.

Hasil analisis sebagaimana dikemukakan di atas sejalan dengan klasifikasi yang dilakukan oleh Mizuguchi (2004:3) dan Wahyuni (2006:101-108). Namun, dari segi bentuk dan penggunaan kata penggolong benda terdapat perbedaan, apalagi jika dibandingkan dengan hasil penelitian Mizuguchi yang berbicara soal kata penggolong benda dalam bahasa Jepang. Begitu juga halnya dengan hasil penelitian yang dilakukan oleh Wahyuni, walaupun pembicaraannya juga tentang kata penggolong benda dalam bahasa Indonesia dan perbandingannya dengan bahasa Jepang, namun terdapat perbedaan bentuk dan penggunaan kata penggolong benda dengan hasil penelitian yang disajikan dalam tulisan ini. Sebagai contoh, bentuk pajangan, pis, renceng, gabung, lonjor, dan sak tidak ditemukan dalam Wahyuni. Begitu pula halnya dengan bentuk biji, walaupun bentuk ini juga ditemukan dalam Wahyuni, namun dalam penggunaannya terdapat perbedaan. Jika dalam Wahyuni bentuk biji hanya digunakan untuk buah atau benda yang kecil-kecil, dalam penelitian ini bentuk biji juga digunakan untuk buah yang besar dan benda yang lebih beragam. Bahkan, kata penggolong biji, di pasar induk tradisional di Jakarta, digunakan untuk pengganti kata penggolong buah, helai, butir, bungkus, dan batang. Hal itu disebabkan oleh penggunaan kata penggolong benda yang beragam dan tempat penggunaan yang juga berbeda-beda.

\section{SIMPULAN}

Berdasarkan hasil dan pembahasan di atas dapat ditarik simpulan sebagai berikut. Pertama, kata penggolong benda, baik yang digunakan dalam jual beli di pasar induk tradisional di Jakarta maupun di Surabaya, ditemukan sebanyak empat puluh tiga bentuk. Tiga puluh empat di antaranya digunakan, baik di pasar induk tradisional di Jakarta maupun di Surabaya; empat bentuk hanya digunakan di pasar induk tradisional di Jakarta; dan lima bentuk hanya digunakan di pasar induk tradisional di Surabaya.

Kedua, kata penggolong benda tersebut dapat diklasifikasikan atas tiga jenis, yaitu: (1) kata penggolong benda individual, yakni kata penggolong benda un- 
tuk menghitung unit terkecil atau untuk menghitung secara satu persatu bendabenda padat yang nyata; (2) kata penggolong benda kolektif, yakni kata penggolong untuk menghitung benda-benda yang terbentuk dari dikumpulkannya beberapa unit terkecil atau beberapa individual; dan (3) kata penggolong benda yang berupa satuan ukuran, yakni kata penggolong pembantu ketika mengukur suatu benda berdasarkan ukurannya dan benda tersebut dipahami bukan sebagai unit terkecil dari benda itu sendiri.

Ketiga, kata penggolong yang dominan ditemukan di pasar induk tradisional di Jakarta dan Surabaya adalah kata penggolong yang berupa satuan ukuran. Hal itu sangat sesuai sebab dalam jual beli memang diperlukan ukuran yang jelas. Kata penggolong benda yang berupa satuan ukuran dapat dikelompokkan lagi atas satuan ukuran dalam takaran yang pasti dan satuan ukuran dalam takaran yang tidak pasti. Kata penggolong benda yang berupa satuan ukuran dalam takaran yang pasti adalah satuan ukuran yang digunakan secara internasional, yaitu berupa ukuran panjang, ukuran berat, dan ukuran isi. Sementara, kata penggolong satuan ukuran dalam takaran yang tidak pasti, umumnya ditemukan dalam takaran berbentuk wadah.

\section{UCAPAN TERIMA KASIH}

Tulisan ini merupakan bagian dari hasil penelitian yang berjudul "Pembangunan Karakter Bangsa melalui Kajian Variasi Kata Penggolong Benda" yang didanai oleh DP2M Dikti melalui Hibah Penelitian Desentralisasi dengan Skim Penelitian Unggulan Perguruan Tinggi (PUPT). Atas dana yang diberikan tersebut, penulis mengucapkan terima kasih. Terima kasih juga diucapkan kepada semua informan yang telah memberikan data lisan kata penggolong benda di kedua pasar induk tradisional di Jakarta dan Surabaya. Ucapan terima kasih juga ditujukan kepada semua pihak yang ikut membantu sehingga penelitian tersebut dapat terlaksana sesuai dengan yang diharapkan.

\section{DAFTAR PUSTAKA}

Aikhenvald, Alexandra Y. 2000. Classifier: A Typology of Noun Categorization Devices. New York: Oxford University Press.

Brataatmaja, T. Heru Kasida. 1987. Morfologi Bahasa Indonesia. Yogyakarta: Kanisius.

Creswell, John W. 2002. Research Design: Qualitative \& Quantitative Approaches. (Alih Bahasa: Angkatan III \& IV KIK-UI bekerja sama dengan Nur Khabibah). Jakarta: KIK Press.

Hadidjaja, Tardjan. 1956. Tata Bahasa Indonesia. Yogyakarta: UP Indonesia.

Hasan, Alwi dkk.2000 Tata Bahasa Baku Bahasa Indonesia. Jakarta: Balai Pustaka.

Kentjono, Djoko dkk. 2004. Tata Bahasa Acuan Bahasa Indonesia untuk Penutur Asing. Jakarta: Wedatama Widya Sastra.

Keraf, Gorys. 1984. Tata Bahasa Indonesia. Ende, Flores: Nusa Indah.

Kridalaksana, Harimurti. 1994. Kamus Linguistik. Jakarta: Gramedia Pustaka Utama

Mahsun. 2005. Metode Penelitian Bahasa. Jakarta: Raja Grafindo Persada.

Mizuguchi, Shinobu. 2004. "Ruibetsushi to wa Nanika" dalam Ruibetsushi no Taishou. (Ed. Mizuguchi, Shinobu dan Nishimitsu Yoshihiro). Hal. 3-22. Tokyo: Kuroshio Shuppan.

Ramlan, M. 1983. Morfologi: Suatu Tinjauan Deskriptif. Yogyakarta: UP Karyono.

Ramlan, M.1991. Tata Bahasa Indonesia: Penggolongan Kata. Yogyakarta: Andi Offset.

Sudaryanto. 1993. Metode dan Aneka Teknik Analisis Bahasa. Yogyakarta: Duta Wacana University Press.

Wahyuni, Sri. 2006. "Indonesiago no Ruibetsushi" dalam Jurnal Memoir of the 
Faculty of Education Shimane University. Volume 39, 101-118.

Wahyuni, Sri. 2010. “Kata Bantu Bilangan Penghitung Binatang dalam Bahasa Jepang" dalam Jurnal Linguistika Kultura. Volume 4 Nomor 1. Jurusan Sastra Inggris Fakultas Sastra Universitas Andalas.
Walujeng, Ayu. 2002. Inti Sari Kata Bahasa Indonesia. Surabaya: Serba Jaya.

Yamamoto, Kasumi and Keil Frank. 2000. "The Acquisition of Japanese Numeral Classifier: Linkage between Grammatical Form and Conceptual Categories". Journal of East Asian Linguistic 9, 379-409. 